\title{
EFEKTIFITAS IKLAN GO-JEK PENGGUNA MEDIA SOSIAL KOTA PADANG
}

\author{
Tri Irfa Indrayani ${ }^{1)}$ Asrizal $^{2)}$ Nurdiah Shalat ${ }^{3)}$ \\ Fakultas Ekonomi, Universitas Muhammadiyah Sumatera Barat ${ }^{1223)}$ \\ triirfaindrayani1@gmail.com ${ }^{1)}$, asrizal@yahoo.co.id ${ }^{2)}$,nurdiah.shalat@gmail.com ${ }^{3)}$
}

\begin{abstract}
Research Objectives to measure and analyze the effectiveness of Go-Jek online advertising on social media. This study uses a sample to residents who live in Padang City and are social media users. Sampling was done by Purpose sampling with 100 respondents. The data analysis technique used is the EPIC method, which consists of; empathy (empathy), persuasion (persuasion), impact (impact), and communication (communication).

The EPIC analysis results partially for each variable are in the "effective" range because the average value of empathy $=3.9375$, persuasion $=3.9273$, impact $=3.8175$, and communication $=3.92$. And the EPIC rate which is the average value of the whole variable is at 3.9. This value is in the "effective" range on the effectiveness scale. This shows that Go-Jek online advertisements through social media are considered effective in attracting audience empathy, effective in influencing audience buying interest, effective in leaving a good impression on the audience, and effective in delivering messages clearly, well, and correctly.
\end{abstract}

Keywords: Effectiveness, EPIC Method

Abstrak : Tujuan Penelitian untukmengukur dan menganalisis efektivitas iklan online Go-Jekdi media sosial. Penelitian ini menggunakan sampel kepadawarga yang berdomisili di Kota Padang dan merupakan pengguna media social. Pengambilan sampel dilakukan secara Purpose samplingdengan 100 orang responden. Teknik analisis data yang digunakan adalah metode EPIC, yang terdiri dari; empathy (empati), persuasion (persuasi), impact (dampak), dan communication (komunikasi).

Hasilanalisis EPIC secara parsial untuk masing-masing variabel berada di rentang "efektif" karena nilai rata-rata empathy $=3,9375$, persuasion $=3,9273$, impact $=3,8175$, dan communication $=3,92$. Dan nilai EPIC rate yang merupakan nilai rata-rata secara keseluruhan variabel berada di angka 3,9. Nilai ini dalam rentang "efektif" pada skala efektifitas. Hal ini menunjukkan iklan online Go-Jek melalui media sosial dinilai efektif dalam menarik empati audiens, efektif dalam mempengaruhi minat beli audiens, efektif dalam meninggalkan kesan yang baik pada audiens, dan efektif dalam menyampaikan pesan secara jelas, baik, dan benar.

\section{Kata kunci : Efektifitas, Metode EPIC}

\section{A. PENDAHULUAN}

Seiring dengan perkembangan teknologi dan informasi, perkembangan internet saat ini semakin mempermudah pemakainya dalam memahami serta mendapatkan informasi secepat, akurat, serta mencakup kisaran waktu dan ruang yang lebih luas. Berkat perkembangan teknologi ini, masyarakat dapat menikmati berbagai kemudahan yang dapat diakses melalui internet. Penggunaan internet di Indonesia juga semakin meningkat seiring menjamurnya perangkat komputer, laptop, dan smartphone. Menurut data dari situs Internet World Stat, jumlah pengguna internet akhir th 2017 di Indonesia mencapai 143,2 Juta pengguna.

Tabel 1. Pengguna Internet di Indonesia tahun 2014-2017

\begin{tabular}{|c|c|c|c|}
\hline Tahun & Jumlah Pengguna & Populasi & $\begin{array}{c}\text { Persentase } \\
(\mathbf{\%})\end{array}$ \\
\hline 2000 & 2.000 .000 & 206.264 .595 & $1,0 \%$ \\
\hline 2014 & 88.100 .000 & 252.200 .000 & $34,93 \%$ \\
\hline 2015 & 110.200 .000 & 255.461 .700 & $43,13 \%$ \\
\hline
\end{tabular}




\begin{tabular}{|c|c|c|c|}
\hline 2016 & 132.700 .000 & 258.316 .051 & $51,37 \%$ \\
\hline 2017 & 143.260 .000 & 262.000 .000 & $54,68 \%$ \\
\hline
\end{tabular}

Sumber: http://www.internetworldstats.com/asia/id.htm, diakses 18 Maret 2019.

Tingginya pengguna internet di Indonesia memunculkan banyak ide bagi sebahagian orang dan sebagian besar perusahaan untuk menggunakannya sebagai media promosi. Promosi dapat dilakukan dengan berbagai cara, antara lain adalah periklanan. Beriklan di media sosial memang lebih cepat dalam hal penyampaian pesan ke audiens jika dibandingkan dengan iklan online konvensional seperti banner atau pop-up ads.

Menurut data terbaru dari We Are Social yang bekerja sama dengan Hootsuite, pengguna internet di Indonesia pada awal tahun 2018 mencapai 132,7 juta dan 130 juta di antaranya merupakan pengguna media sosial aktif.

Dilihat dari data tersebut hampir seluruh pengguna internet di Indonesia adalah pengguna aktif mediasosial. Perusahaan penyedia barang dan jasa pun berbondong- bondong memasang iklan di berbagai media sosial seperti Facebook, Twitter, dan Instragram dan lainnya. Tidak terkecuali perusahaan yang menyediakan jasa ojek online, PT. GojekIndonesia.

PT Gojek Indonesia (Go-Jek) merupakan salah satu perusahaan yang akrab dengan pengguna internet di Indonesia. Perusahaan ini bergerak di bidang penyediaan jasa transportasi yang konsepnya diadaptasi dari jasa transportasi tradisional, yaitu ojek. Strategi pemasarannya memanfaatkan internet sebagai sarana untuk mempromosikan jasa yang ditawarkan. Terlebih lagi Go-Jek sedang gencar melakukan ekspansi usahanya ke berbagai daerah di Indonesia, salah satunya Kota Padang di Sumatera Barat. Dengan kecanggihan periklanan media sosial, audiens yang berdomisili di Kota Padang secara otomatis disuguhi berbagai promosi dari Go-Jek saat membuka halaman media sosial. Strategi ini sangat tepat karena hampir seluruh proses pembelian layanan Go-Jek dilakukan dalam aplikasi smartphone, yang berarti bahwa calon konsumen yang disasar sudah sesuai dengan audiens iklan yang dipasang.

Menurut Kotler dan Amstrong (2006: 150) periklanan adalah semua bentuk terbayar dari presentasi nonpribadi dan promosi ide, barang, atau jasa oleh sponsor tertentu. Tujuan periklanan bisa digolongkan berdasarkan tujuan utama, apakah tujuannya menginformasikan, membujuk, atau mengingatkan. Periklanan dibuat tidak hanya untuk menarik konsumen, namun juga untuk diukur keefektifannya, untuk menghindari kesalahan yang membawa konsekuensi kerugian finansial yang besar. Jika dari pengukuran efektivitas didapat fakta bahwa iklan mereka tidak membawa pengaruh yang diharapkan, maka keputusan untuk menghentikan pembiayaan atau peredaran iklan tersebut merupakan sebuah keputusan yang logis dan rasional. Atau jika dari pengukuran efektivitas diketahui bahwa iklan tersebut tidak berhasil membujuk segmen konsumen yang ditargetkan, maka metode lain dapat segera dipertimbangkan.

\title{
B. METODE PENELITIAN
}

Penelitian ini merupakan studi tentang efektifitas iklan go-jek pengguna media sosial di Kota Padang. Populasi dalam penelitian ini adalahseluruh pengguna media sosial yang berdomisili di Kota Padang dan pernah melihat iklan online Go-Jek di media sosial, dengan jumlah sampel 100 responden yang menggunakan metode purposive sampling. Waktu penelitian dilaksanakan pada bulan Juni 2019 sampai Juli 2019 melalui penyebaran kuisioner secara online dalambentuk Google Form.

\section{HASIL DISKUSI}

\author{
1. Uji Validitas dan Uji Reliabilitas \\ a. Uji Validitas EPIC (Empathy, Persuasion DAN, Impact, Communication)
}


Tabel 2. Uji Validitas EPIC

\begin{tabular}{|c|c|c|c|c|c|}
\hline No. & \multicolumn{2}{|c|}{ Dimensi (variabel) } & $R$ tabel & R hitung & Keterangan \\
\hline \multirow[t]{4}{*}{1.} & \multirow{4}{*}{ Empathy $\left(X_{1}\right)$} & $\mathrm{X}_{1.1}$ & 0,1966 & 0,525 & VALID \\
\hline & & $\mathrm{X}_{1.2}$ & 0,1966 & 0,675 & VALID \\
\hline & & $\mathrm{X}_{1.3}$ & 0,1966 & 0,590 & VALID \\
\hline & & $\mathrm{X}_{1.4}$ & 0,1966 & 0,731 & VALID \\
\hline \multirow[t]{4}{*}{2.} & \multirow{4}{*}{ Persuasion $\left(X_{2}\right)$} & $\mathrm{X}_{2.1}$ & 0,1966 & 0,696 & VALID \\
\hline & & $\mathrm{X}_{2.2}$ & 0,1966 & 0,661 & VALID \\
\hline & & $\mathrm{X}_{2.3}$ & 0,1966 & 0,524 & VALID \\
\hline & & $\mathrm{X}_{2.4}$ & 0,1966 & 0,623 & VALID \\
\hline \multirow[t]{4}{*}{3.} & \multirow[t]{4}{*}{$\operatorname{Impact}\left(X_{3}\right)$} & $\mathrm{X}_{3.1}$ & 0,1966 & 0,744 & VALID \\
\hline & & $\mathrm{X}_{3.2}$ & 0,1966 & 0,727 & VALID \\
\hline & & $\mathrm{X}_{3.3}$ & 0,1966 & 0,714 & VALID \\
\hline & & $\mathrm{X}_{3.4}$ & 0,1966 & 0,753 & VALID \\
\hline \multirow[t]{4}{*}{4.} & \multirow{4}{*}{$\begin{array}{l}\text { Communication } \\
\left(X_{4}\right)\end{array}$} & $\mathrm{X}_{4.1}$ & 0,1966 & 0,614 & VALID \\
\hline & & $\mathrm{X}_{4.2}$ & 0,1966 & 0,795 & VALID \\
\hline & & $\mathrm{X}_{4.3}$ & 0,1966 & 0,764 & VALID \\
\hline & & $\mathrm{X}_{4.4}$ & 0,1966 & 0,667 & VALID \\
\hline
\end{tabular}

\section{Sumber: Data diolah, 2019.}

Dari data diatas diketahui bahwa hasil dari pengujian validitas dari tiap-tiap pertanyaan pada semua variabel yang mengindikasikan nilai epic dinyatakan valid karena $r_{\mathrm{hit}}>r_{\mathrm{ab}}(0,1966)$.

\section{b. Uji RealiabilitasEPIC}

Tabel 3. Uji Reliabilitas EPIC

\begin{tabular}{|l|l|c|c|c|}
\hline No. & Dimensi (variabel) & R hitung & $\begin{array}{c}\text { Cronbach } \\
\text { alpha }\end{array}$ & Keterangan \\
\hline 1. & Empathy $\left(X_{1}\right)$ & 0,919 & 0,61 & Reliabel \\
\hline 2. & Persuasion $\left(X_{2}\right)$ & 0,917 & 0,61 & Reliabel \\
\hline 3. & Impact $\left(X_{3}\right)$ & 0,912 & 0,61 & Reliabel \\
\hline 4. & Communication $\left(X_{4}\right)$ & 0,915 & 0,61 & Reliabel \\
\hline
\end{tabular}

Sumber: Data diolah, 2019.

Dari data diatas diketahui bahwa hasil dari pengujian reliabilitas masing-masing dimensi (variabel) dari kuesioner adalah reliable yang berarti jawaban responden pada setiap pertanyaan stabil/konsisten.

\section{Efektivitas Iklan Online Go-Jek (Analisis EPIC)}

Pengukuran efektivitas iklan menggunakan teknik EPIC Model yang bertujuan untuk mengetahui dampak komunikasi iklan terhadap konsumen dalam mempengaruhi keputusan konsumen. EPIC Model terdiri atas empat dimensi, yaitu dimensi empathy, dimensi persuasion, dimensi impact, dan dimensi communication. Dimensi-dimensi tersebut terwakili oleh 16 pernyataan yang diajukan kepada responden melalui kuesioner 


\section{a. Dimensi Emphaty (X1)}

Tabel 4. Dimensi Emphaty (X1)

\begin{tabular}{|l|c|c|c|c|c|}
\hline \multirow{2}{*}{ Pilihan Jawaban } & \multirow{2}{*}{ Bobot } & Frekuensi & Frekuensi & Frekuensi & Freekuensi \\
\cline { 3 - 6 } & & $\mathbf{X}_{\mathbf{1 . 1}}$ & $\mathbf{X}_{\mathbf{1 . 2}}$ & $\mathbf{X}_{\mathbf{1 . 3}}$ & $\mathbf{X}_{\mathbf{1 . 4}}$ \\
\hline Sangat Setuju & 5 & 13 & 14 & 18 & 27 \\
\hline Setuju & 4 & 53 & 56 & 71 & 64 \\
\hline Biasa Saja & 3 & 32 & 28 & 7 & 7 \\
\hline Tidak Setuju & 2 & 1 & 2 & 4 & 2 \\
\hline Sangat Tidak Setuju & 1 & 1 & 0 & 0 & 0 \\
\hline Total & & 100 & 100 & 100 & 100 \\
\hline
\end{tabular}

Sumber: Data diolah, 2019.

Dari data diatas diketahui tingkat frekuensi dari tiap-tiap pernyataan yang mengindentifikasikan nilai dari dimensi empathy $\left(X_{1}\right)$. Kemudian menghitung nilai dari tiap frekuensi untuk mengetahui posisi keputusan dari dimensi tersebut, yaitu:

$$
\begin{aligned}
& X_{1.1}=\frac{(1 \times 1)+(2 \times 1)(3 \times 32)+(4 \times 53)+(5 \times 13)}{100}=3,76 \\
& X_{1.2}=\frac{(1 \times 0)+(2 \times 1)(3 \times 28)+(4 \times 56)+(5 \times 14)}{100}=3,8 \\
& X_{1.3}=\frac{(1 \times 0)+(2 \times 4)(3 \times 7)+(4 \times 71)+(5 \times 18)}{100}=4,03 \\
& X_{1.4}=\frac{(1 \times 0)+(2 \times 2)(3 \times 7)+(4 \times 64)+(5 \times 27)}{100}=4,16
\end{aligned}
$$

Berdasarkan hasil análisis di atas, tampak bahwa:

1) Dimensi empathy $\left(X_{1.1}\right)$, yaitu "Saya menyukai iklan media sosial Go-Jek" mendapat nilai rata-rata 3,76. Ini berarti responden menyukai iklan yang ditampilkan.

2) Dimensi empathy $\left(X_{1.2}\right.$ dan $\left.X_{1.3}\right)$, yang merupakan pernyataan bahwa iklan media sosial Go-Jek memiliki daya tarik tinggi dan lebih unggul dibandingkan pesaingnya masingmasing mendapatkan nilai rata-rata 3,8 dan 4,03 yang menandakan bahwa iklan Go-Jek mendapat respon yang baik dari audiens.

3) Dimensi empathy $4\left(X_{1.4}\right)$, yaitu "Layanan yang ditawarkan oleh Go-Jek sangat sesuai dengan kebutuhan Saya" mendapat nilai rata-rata 4,16 yang berarti bahwa iklan Go-Jek berhasil menarik minat calon konsumen dengan memperlihatkan hubungan antara layanan yang ditawarkan dengan kebutuhan calon konsumennya.

Total skor rata-rata dimensi empathy:

$$
\bar{X}_{1}=\frac{3,76+3,8+4,03+4,16}{4}=3,9375
$$

Berdasarkan hasil perhitungan rata-rata dimensi empathy yaitu sebesar 3,9375. Skor tersebut dimasukkan ke dalam rentang skala keputusan yang dapat dilihat pada Gambar 1, sebagai berikut:

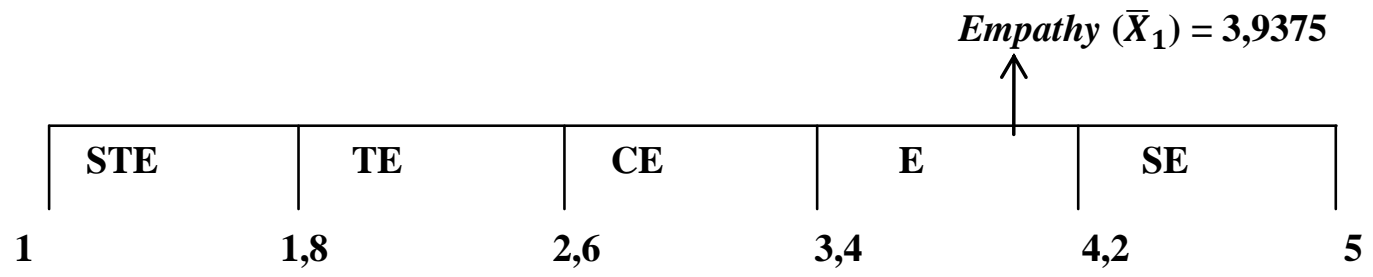

Gambar 1. Nilai Rata-rata Dimensi Empathy $\left(\bar{X}_{1}\right)$. 
Hasil analisis pengukuran efektivitas dimensi empathy pada iklan online Go-Jek menunjukkan bahwa iklan tersebut termasuk dalam rentang skala efektif dengan rata-rata berbobot 3,9375 yang berarti iklan ini membuat responden merasakan reaksi positif terhadap pesan iklan, serta mampu menciptakan hubungan antar konsumen dengan produk melalui isi pesan yang relevan secara personal.

\section{b. Dimensi Persuasion $\left(\mathrm{X}_{2}\right)$}

\section{Tabel 5. Dimensi Persuasion (X2)}

\begin{tabular}{|l|c|c|c|c|c|}
\hline \multirow{2}{*}{ Pilihan Jawaban } & \multirow{2}{*}{ Bobot } & Frekuensi & Frekuensi & Frekuensi & Freekuensi \\
\cline { 3 - 6 } & & $\boldsymbol{X}_{\mathbf{2 . 1}}$ & $\boldsymbol{X}_{\mathbf{2 . 2}}$ & $\boldsymbol{X}_{\mathbf{2 . 3}}$ & $\boldsymbol{X}_{\mathbf{2 . 4}}$ \\
\hline Sangat Setuju & 5 & 16 & 11 & 37 & 16 \\
\hline Setuju & 4 & 72 & 61 & 60 & 66 \\
\hline Biasa Saja & 3 & 12 & 25 & 3 & 18 \\
\hline Tidak Setuju & 2 & 0 & 3 & 0 & 0 \\
\hline Sangat Tidak Setuju & 1 & 0 & 0 & 0 & 0 \\
\hline Total & 100 & 100 & 100 & 100 \\
\hline
\end{tabular}

Sumber: Data diolah, 2019.

Dari data diatas diketahui tingkat frekuensi dari tiap-tiap pertanyaan yang mengindentifikasikan nilai dari dimensi persuasion. Kemudian menghitung nilai dari tiap frekuensi untuk mengetahui posisi keputusan dari dimensi tersebut, yaitu:

$$
\begin{aligned}
& X_{2.1}=\frac{(1 \times 0)+(2 \times 0)(3 \times 12)+(4 \times 72)+(5 \times 16)}{100}=4,04 \\
& X_{2.2}=\frac{(1 \times 0)+(2 \times 3)(3 \times 25)+(4 \times 61)+(5 \times 11)}{100}=3,8 \\
& X_{2.3}=\frac{(1 \times 0)+(2 \times 0)(3 \times 3)+(4 \times 60)+(5 \times 37)}{100}=4,34 \\
& X_{2.4}=\frac{(1 \times 0)+(2 \times 0)(3 \times 18)+(4 \times 66)+(5 \times 16)}{100}=3,98
\end{aligned}
$$

Berdasarkan hasil analisis di atas, dapat dilihat bahwa:

1. Dimensi persuasion $1\left(X_{2.1}\right)$, yakni "Saya tertarik dengan layanan yang ditawarkan oleh Go-Jek" mendapat nilai rata-rata 4,04. Ini berarti bahwa iklan telah mendapat perhatian dari calon konsumen yang membuka jalan untuk mendapatkan kepercayaan.

2. Dimensi persuasion 2 dan $3\left(X_{2.1}\right.$ dan $X_{2.1}$, yang berisi pernyataan tentang keinginan untuk sekedar mencoba layanan Go-Jek maupun saat sedang dibutuhkan setelah melihat iklan yang dipasang mendapatkan nilai rata-rata 3,8 dan 4,34. Ini berarti bahwa iklan yang dipasang berhasil mengajak calon konsumen untuk mencoba dan menggunakan layanan Go-Jek.

3. Dimensi persuasion $4\left(X_{2.4}\right)$, yakni "Saya akan merekomendasikan Go-Jek kepada teman" mendapat nilai rata-rata 3,98. Ini berarti bahwa selain merasa cocok dan ingin menggunakan layanan Go-Jek untuk diri sendiri, audiens juga merasa bahwa layanan Go-Jek akan dapat diterima dengan baik oleh orang lain.

Total skor rata-rata dimensi persuasion:

$\overline{\mathrm{X}}_{2}=\frac{4,04+3,8+4,34+3,98}{4}=3,9273$

Berdasarkan hasil perhitungan rata-rata dimensi persuasion $\left(\overline{\mathrm{X}}_{2}\right)$ yaitu sebesar 3,9273. Skor tersebut dimasukkan ke dalam rentang skala keputusan yang dapat dilihat pada Gambar 2 berikut: 


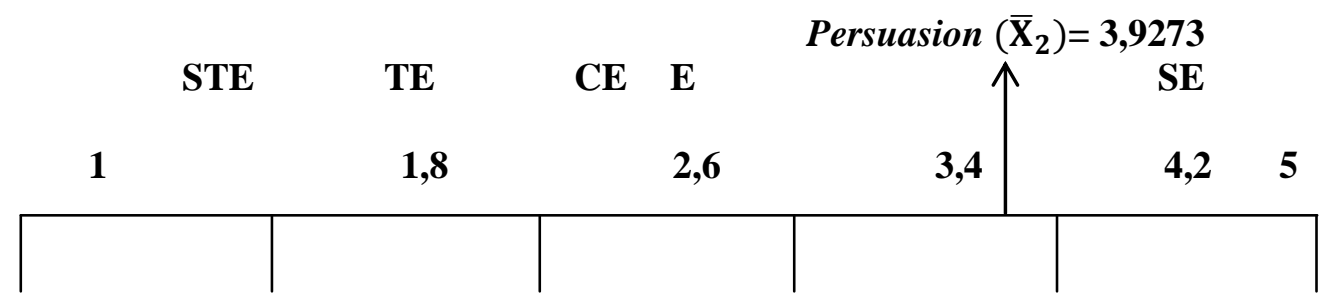

Gambar 2. Nilai Rata-rata Dimensi Persuasion $\left(\overline{\mathbf{X}}_{2}\right)$

Hasil analisis pengukuran efektivitas dimensi persuasion pada iklan online GoJek menunjukkan bahwa iklan tersebut termasuk dalam kategori efektif dengan ratarata berbobot 3,9273 dimana dengan tingkat keterlibatan konsumen terhadap produk mengakibatkan dampak persuasi, pengingat atau penguat keputusan beli konsumen terhadap produk.

\section{c. Dimensi Impact $\left(\mathrm{X}_{3}\right)$}

Tabel 6. Dimensi Impact (X3)

\begin{tabular}{|l|c|c|c|c|c|}
\hline \multirow{2}{*}{ Pilihan jawaban } & \multirow{2}{*}{ Bobot } & Frekuensi & Frekuensi & Frekuensi & Freekuensi \\
\cline { 3 - 6 } & & $\mathbf{X}_{\mathbf{3 . 1}}$ & $\mathbf{X}_{\mathbf{3 . 2}}$ & $\mathbf{X}_{\mathbf{3 . 3}}$ & $\mathbf{X}_{\mathbf{3 . 4}}$ \\
\hline Sangat Setuju & 5 & 12 & 16 & 16 & 13 \\
\hline Setuju & 4 & 52 & 53 & 57 & 68 \\
\hline Biasa Saja & 3 & 34 & 24 & 21 & 17 \\
\hline Tidak Setuju & 2 & 2 & 7 & 6 & 2 \\
\hline Sangat Tidak Setuju & 1 & 0 & 0 & 0 & 0 \\
\hline Total & & $\mathbf{1 0 0}$ & $\mathbf{1 0 0}$ & $\mathbf{1 0 0}$ & $\mathbf{1 0 0}$ \\
\hline
\end{tabular}

Sumber: Data diolah, 2019.

Dari data diatas diketahui tingkat frekuensi dari tiap-tiap pertanyaan yang mengindentifikasikan nilai dari dimensi impact. Kemudian menghitung nilai dari tiap frekuensi untuk mengetahui posisi keputusan dari dimensi tersebut, yaitu:

$$
\begin{aligned}
& X_{3.1}=\frac{(1 \times 0)+(2 \times 2)(3 \times 34)+(4 \times 52)+(5 \times 12)}{100}=3,74 \\
& X_{3.2}=\frac{(1 \times 0)+(2 \times 7)(3 \times 24)+(4 \times 53)+(5 \times 16)}{100}=3,78 \\
& X_{3.3}=\frac{(1 \times 0)+(2 \times 6)(3 \times 21)+(4 \times 57)+(5 \times 16)}{100}=3,83 \\
& X_{3.4}=\frac{(1 \times 0)+(2 \times 0)(3 \times 18)+(4 \times 66)+(5 \times 16)}{100}=3,98
\end{aligned}
$$

Berdasarkan hasil analisis di atas, dapat dilihat bahwa:

1. Dimensi impact $1\left(X_{3.1}\right)$, yakni "Iklan Go-Jek lebih kreatif dibandingkan dengan iklan pesaingnya" mendapat nilai rata-rata berbobot 3,74. Ini menandakan bahwa dari segi penyajian iklan, Go-Jek meninggalkan kesan yang baik di benak audiens.

2. Dimensi impact 2,3 , dan $4\left(X_{3.2}, X_{3.3}\right.$ dan $\left.X_{3.4}\right)$ tentang slogan Go-Jek yaitu "An Ojek for Every Need" mendapat nilai rata-rata berbobot masing-masing 3,78, 3,83 , dan 3,92. Ketiganya menunjukkan bahwa slogan yang diusung oleh Go-Jek mudah diingat, dipahami dan juga mewakili layanan Go-Jek.

Total skor rata-rata dimensi impact:

$$
\overline{\mathrm{X}}_{3}=\frac{3,74+3,78+3,83+3,92}{4}=3,8175
$$


Berdasarkan hasil perhitungan rata-rata dimensi impact yaitu sebesar 3,8175. Skor tersebut dimasukkan ke dalam rentang skala keputusan yang dapat dilihat pada Gambar 3:

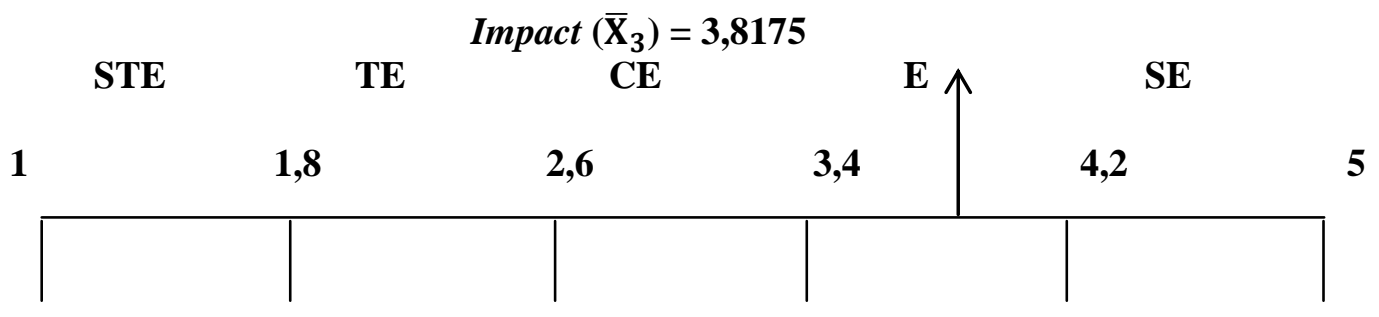

Gambar 3. Nilai Rata-rata Dimensi Impact $\overline{\mathbf{X}}_{3}$.

Hasil analisis pengukuran efektivitas dimensi $\operatorname{impact}\left(\overline{\mathrm{X}}_{3}\right)$ dalam iklan online Go-Jek menunjukkan bahwa iklan tersebut termasuk dalam kategori efektif dengan bobot rata-rata sebesar 3,8175 baik melalui pengetahuan produk melalui asosiasi produk dan repetisi iklan yang bertujuan untuk menangkap perhatian konsumen dengan frekuensi iklan yang berulang-ulang

\section{d. Dimensi Communication $\left(X_{4}\right)$}

Tabel 7. Dimensi Communication (X4)

\begin{tabular}{|l|c|c|c|c|c|}
\hline \multirow{2}{*}{ Pilihan jawaban } & \multirow{2}{*}{ Bobot } & Frekuensi & Frekuensi & Frekuensi & Frekuensi \\
\cline { 3 - 6 } & & $\mathrm{X}_{4.1}$ & $\mathrm{X}_{4.2}$ & $\mathrm{X}_{4.3}$ & $\mathrm{X}_{4.4}$ \\
\hline Sangat Setuju & 5 & 11 & 11 & 16 & 15 \\
\hline Setuju & 4 & 84 & 72 & 64 & 58 \\
\hline Biasa Saja & 3 & 4 & 15 & 15 & 19 \\
\hline Tidak Setuju & 2 & 1 & 2 & 5 & 8 \\
\hline Sangat Tidak Setuju & 1 & 0 & 0 & 0 & 0 \\
\hline Total & & $\mathbf{1 0 0}$ & $\mathbf{1 0 0}$ & $\mathbf{1 0 0}$ & $\mathbf{1 0 0}$ \\
\hline
\end{tabular}

Sumber: Data diolah, 2019.

Dari data diatas diketahui tingkat frekuensi dari tiap-tiap pertanyaan yang mengindentifikasikan nilai dari dimensi communication $\left(X_{4}\right)$. Kemudian menghitung nilai dari tiap frekuensi untuk mengetahui posisi keputusan dari dimensi tersebut, yaitu:

$$
\begin{gathered}
X_{4.1}=\frac{(1 \times 0)+(2 \times 1)(3 \times 4)+(4 \times 84)+(5 \times 11)}{100}=4,05 \\
X_{4.2}=\frac{(1 \times 0)+(2 \times 2)(3 \times 15)+(4 \times 72)+(5 \times 11)}{100}=3,92 \\
X_{4.3}=\frac{(1 \times 0)+(2 \times 5)(3 \times 15)+(4 \times 72)+(5 \times 11)}{100}=3,91 \\
X_{4.4}=\frac{(1 \times 0)+(2 \times 8)(3 \times 19)+(4 \times 58)+(5 \times 15)}{100}=3,8
\end{gathered}
$$

Berdasarkan hasil analisis di atas, dapat dilihat bahwa:

1. Dimensi communication 1 dan $2\left(X_{4.1}\right.$ dan $\left.X_{4.2}\right)$ masing-masing mendapatkan nilai rata-rata berbobot sebesar 4,05 dan 3,92. Ini menandakan bahwa komunikasi yang dilakukan melalui iklan media sosial sudah berhasil menyampaikan pesan kepada audiens. 
2. Dimensi communication 3 dan $4\left(X_{4.3}\right.$ dan $\left.X_{4.4}\right)$ masing-masing mendapatkan nilai rata-rata berbobot sebesar 3,91 dan 3,8. Ini berarti bahwa iklan media sosial telah menyediakan informasi tentang layanan Go-Jek dengan baik sehingga mudah dimengerti oleh audiens.

Total skor rata-rata dimensi impact adalah sebagai berikut:

$$
\overline{\mathrm{X}}_{4}=\frac{4,05+3,92+3,91+3,8}{4}=3,92
$$

Berdasarkan hasil perhitungan rata-rata dimensi communication $\left(\overline{\mathrm{X}}_{3}\right)$ yaitu sebesar 3,815 . Skor tersebut dimasukkan ke dalam rentang skala keputusan yang dapat dilihat pada Gambar 4, sebagai berikut:

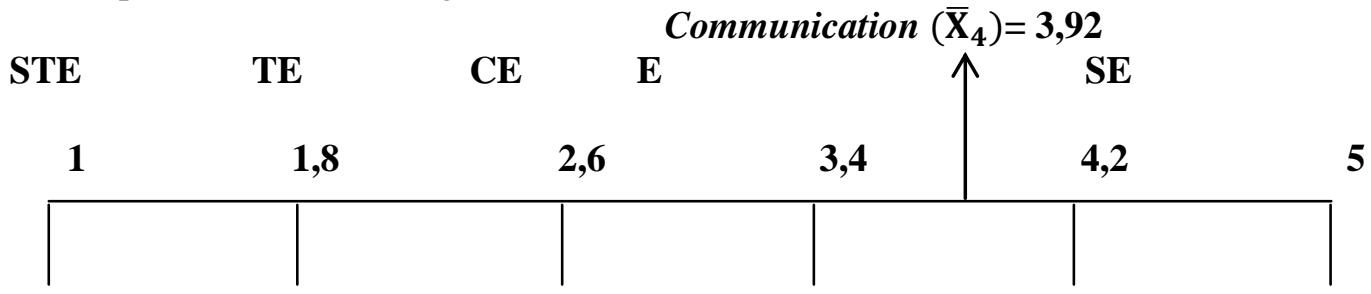

Gambar 4. Nilai Rata-rata Dimensi Communication $\left(\overline{\mathbf{X}}_{4}\right)$.

Hasil analisis pengukuran efektivitas dimensi communication $\left(\overline{\mathrm{X}}_{4}\right)$ dalam iklan online Go-Jek menunjukkan bahwa iklan tersebut termasuk dalam kategori efektif dengan skor rata-rata 3,92 yang menginformasikan bahwa calon konsumen dapat mengenali dan mengingat pesan utama yang disampaikan dalam iklan dengan baik. Selain itu iklan juga meninggalkan kesan yang kuat dan pemahaman konsumen akan pesan iklan.

\section{e. EPIC Rate}

Secara keseluruhan tabel skor dari keempat dimensi dapat dilihat pada tabel 8 . Perhitungan keempat dimensi tersebut adalah sebagai berikut:

Tabel 8. Skor Rata-rataEPIC

\begin{tabular}{|l|c|c|}
\hline EPIC Model & $\begin{array}{c}\text { SKOR } \\
\text { Rata-rata }(\overline{\boldsymbol{X}})\end{array}$ & KESIMPULAN \\
\hline Empathy $X_{1}$ & 3,9375 & Efektif \\
\hline${\text { Persuasion } X_{2}}$ & 3,9273 & Efektif \\
\hline Impact $X_{3}$ & 3,8175 & Efektif \\
\hline Communication $X_{4}$ & 3,92 & Efektif \\
\hline
\end{tabular}

Sumber: Data diolah, 2019.

EPIC Rate $=\frac{3,9375+3,9273+3,8175+3,92}{4}=3,9$

Berdasarkan perhitungan diatas, hasil akhir dari nilai EPIC rate adalah 3,9 yang jika dimasukkan ke dalam skala penilaian termasuk dalam kategori efektif. Hal ini memperlihatkan bahwa iklan online Go-Jek efektif dalam menarik empati audiens, mempengaruhi minat beli audiens, meninggalkan kesan yang baik, dan menyampaikan pesan secara jelas, baik, dan benar.Secara keseluruhan grafik hasil analisis efektivitas iklan online Go-Jek dengan metode EPIC Model tersaji pada gambar 5: 


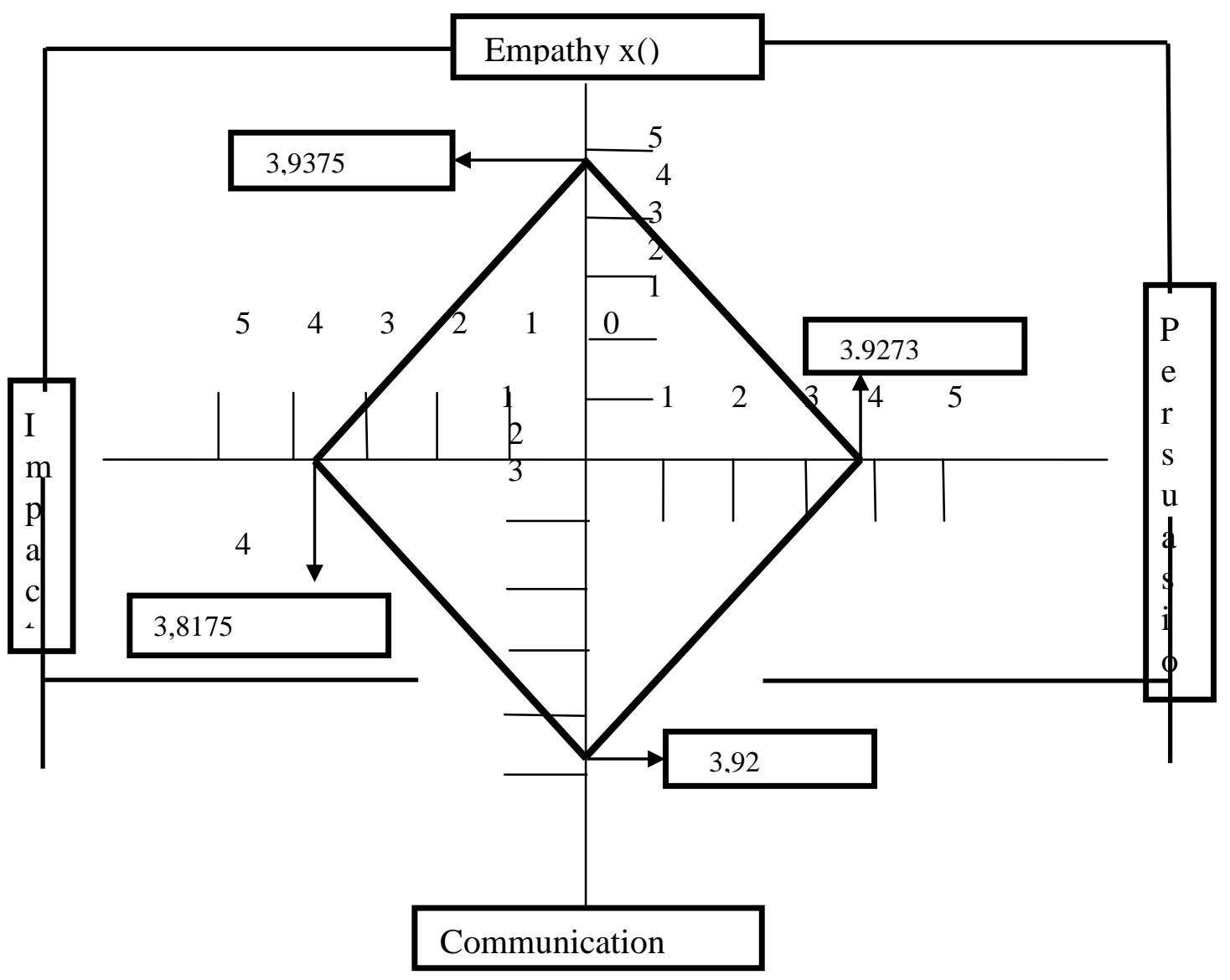

Gambar 5. EPIC Model Iklan Online Go -Jek di Media Sosial.

Hasil diatas secara parsial jika dikaitkan dengan penelitian terdahulu, dimensi Empathy suatu iklan dinyatakan "efektif", sesuai dengan penelitian yang dilakukan oleh Farola B.Y. dan Ade Jauhari Hisyamsah dkk., dinyatakan "cukup efektif" berdasarkan penelitian yang dilakukan oleh Iwan Setyawan dan Raja Frans,dinyatakan "sangat efektif" berdasarkan penelitian yang dilakukan oleh Bagus Riyanto dkk., dimensi Persuasion suatu iklan dinyatakan "efektif", sesuai dengan penelitian yang dilakukan oleh Ade Jauhari Hisyamsah dkk., dinyatakan "cukup efektif" berdasarkan penelitian yang dilakukan oleh Farola B.Y., Iwan Setyawan dan Raja Frans,dan dinyatakan "sangat efektif" berdasarkan penelitian yang dilakukan oleh Bagus Riyanto dkk., dimensi Impact suatu iklan dinyatakan "efektif", sesuai dengan penelitian yang dilakukan oleh Farola B.Y., Iwan Setyawan dan Ade Jauhari Hisyamsah dkk., dinyatakan "cukup efektif" berdasarkan penelitian yang dilakukan oleh Raja Frans,dinyatakan "sangat efektif'berdasarkan penelitian yang dilakukan oleh Bagus Riyanto dkk., dimensi Communication suatu iklan dinyatakan "efektif", sesuai dengan penelitian yang dilakukan oleh Farola B.Y., Iwan Setyawan dan Ade Jauhari Hisyamsah dkk., dinyatakan "cukup efektif" berdasarkan penelitian yang dilakukan oleh Raja Frans, dinyatakan "sangat efektif"berdasarkan penelitian yang dilakukan oleh Bagus Riyanto dkk.

Secara keseluruhan berdasarkan nilai EPIC rate jika dikaitkan dengan penelitian terdahulu yang dilakukan oleh Farola B.Y., Iwan Setyawan dan Ade Jauhari Hisyamsah dkk., nilai EPIC rate suatu iklan berada dalam rentang "efektif", penelitian yang dilakukan oleh Raja Frans nilai EPIC rateberada dalam rentang "cukup efektif" dan penelitian yang dilakukan oleh Bagus Riyanto dkk., nilai EPIC rate berada dalam rentang "sangat efektif", pada skala efektifitas. Hal ini menunjukkan bahwa penelitian terdahulu sangat mendukung hasil penelitian ini. 


\section{KESIMPULAN}

Berdasarkan penelitian yang telah dilakukan, didapatkan hasil bahwa iklan online media sosial Go-Jek dengan menggunakan pendekatan EPIC Model, menunjukkan bahwa efektivitas iklan online perusahaan dinilai efektif.

Pengukuran dimensi empathy $\left(\mathrm{X}_{1}\right)$ berada di angka 3,9375menunjukkan bahwa iklan ini masuk dalam rentang skala efektif . Hal ini mengindikasikan bahwa iklan tersebut mampu memberikan informasi dan pesan yang menarik dalam iklan tersebut sehingga disukai oleh konsumen. Pengukuran dimensi persuasion $\left(X_{2}\right)$ berada di angka 3,9273menunjukkan bahwa iklan ini masuk dalam rentang skala efektif. Hal ini mengindikasikan bahwa iklan yang disajikan menarik, terjadi komunikasi iklan yang baik sehingga dapat dikatakan iklan online perusahaan cukup dapat meningkatkan dan menguatkan suatu produk dalam benak konsumen. Iklan tersebut memiliki dampak terhadap keinginan konsumen untuk menggunakan jasa yang disediakan oleh perusahaan.

Kemudian pengukuran dimensi impact $\left(X_{3}\right)$ berada di angka 3,8175menunjukkan bahwa iklan ini masuk dalam rentang skala efektif. Hal ini mengindikasikan bahwa iklan tersebut menonjol dan memberi pengetahuan mengenai produkyang disajikan (knowledge product). Pengukuran dimensi communication $\left(X_{4}\right)$ berada di angka 3,92menunjukkan bahwa iklan ini masuk dalam rentang skala efektif. Hal ini mengindikasikan bahwa iklan tersebut baik dalam menyampaikan pesannya kepada konsumen disebabkan oleh kekuatan kesan yang ditinggalkan dan kejelasan promosi.

\section{SARAN}

Sesuai dengan hasil penelitian maka saran yang dapat peneliti berikan kepada pihak Go-Jek yakni Go-Jek diharapkan mampu untuk mempertahankan keefektifan iklan media sosialnya karena iklan ini dinilai efektif dalam mencapai tujuan periklanan dan mengikuti perkembangan media sosial yang sedang trend di kalangan masyarakat dan iklannya makin kreatif agar tidak kehilangan audiens iklan.

\section{E. DAFTAR PUSTAKA}

Alma, Buchari. 2007. Manajemen Pemasaran \& Pemasaran Jasa. Bandung: CV Alfabeta.

Bagus Riyanto \& Ati Harmoni (2013). Efektifitas Iklan Melalui Jejaring Sosial sebagai salah satu strategi pemasaran keripik pedas maicih.

Farola, B.Y. (2015). Analisis Efektifitas Iklan Sebagai Salah Satu Strategi Pemasaran Perusahaan Percetakan \& Penerbitan di PT. Rambang.

Hisyamsah, A.J., Sulasro, A. \& Suryaningsih, I.B. (2015). Analisis Efektifitas Iklan Online Terhadap Minat Beli Konsumen Murah Grosir di Jember.

Iwan Setyawan (2013). Analisis Efektifitas Iklan Televisi Kopi Instan Top Coffe endorser Iwan Fals.

Kotler, Philip dan Gary Armstrong. 2006. Prinsip-prinsip Pemasaran, Edisi 2, Jilid 2. Jakarta: Erlangga.

Raja Franch (2011). Pengaruh Efektifitas Iklan di Televisi di Ukur dengan EPIC Model Terhadap Sikap Penonton di Pekan Baru. 